\title{
Nittsū's Company History as a Guide to the Early Modern Origins of Japan's Modern Communications
}

\author{
Charles Andrews \\ Transylvania University
}

Historians of the future will no doubt focus on the transformative role of Internet-based communications as they have changed human interaction in the late twentieth and early twenty-first centuries. The introduction of modern postal services in Japan and elsewhere in the nineteenth century produced effects no less profound: citizens were connected to each other and their governments by reliable and relatively speedy delivery of letters, newspapers, and parcels. Japan's postal system was a great success, but the communications practices of the Japanese prior to the establishment of the post played an important role in that success. Courier services - the so-called hikyakuya - of the early modern period survived and ultimately became today's Nippon Tsüun (Nittsü), a global logistical corporation. This article surveys the development of early modern Japanese communications, demonstrating the indispensible role that Nittsu's company history plays in understanding that development.

Toward the end of Shimazaki Tōson's historical novel, Before the Dawn (Yoake mae), the protagonist
Aoyama Hanzō, former headman of a post station during the late Tokugawa period ponders the future. The narrator informs the reader of Hanzō's concerns as a new, centralizing state begins to take shape:

Since the beginning of Meiji, everyone in the country had been confronted with an overwhelming pressure to change everything, from the direction of scholarly inquiry to the last detail of customary behavior. Hanzō was acutely aware of this. Yet there was one thing that seemed incontrovertible to him out of his experience as head of the Magome post station. This was that of all the coming changes, the ones in transportation and communication would result in the most deep-rooted and substantial transformations of society. Their effects would be like those of water, the weakest and most subtle, but in the end the most powerful of all the agents of change. Such changes affected all, high and low, rich and poor. They determined the success or failure of human society. They wove the fabric of history, and changed the maps. And they led to the exchange of all kinds of goods. ${ }^{1}$

\footnotetext{
${ }^{1}$ Shimazaki Tōson, Before the Dawn, William Naff, trans. (Honolulu: University of Hawaii Press, 1987), 641.
} 
Shimazaki wrote Yoake mae in the age of airplanes, automobiles, and telecommunications and well understood what the real Hanzo of early Meiji could not have: the next century and a half would bring changes in communications that have profoundly altered human societies. One of the first of these transformations was in government-operated posts. Of the American postal system, historian Richard John writes that it "spurred a communications revolution that was as profound in its consequences for American public life as the subsequent revolutions that have come to be associated with the telegraph, the telephone, and the computer." John's characterization is no less applicable to the case of Japan. This study looks not to the full development of Japan's national post, but rather to its antecedent systems of overland communication. Its purpose is to demonstrate the singular importance of communications practices during the Tokugawa period to the rapid development of the Meiji post. Without the preexisting systems of public and private communications, the infrastructure upon which they operated, and the institutional knowledge of thousands of "Hanzōs" as the first local postmasters, it is unlikely that the Meiji postal system could have been established as quickly and efficiently.

\section{Forced Cooperation: The Meiji Post and Traditional Courier Companies}

Japan inaugurated a national postal system on 3.1.1871 (April 20), offering service between Tokyo, Kyoto, and Osaka. By the end of 1871 there were 180 post and handling offices and by 1874 the number had grown to 3,245 . In those years the volume of items handled expanded dramatically, growing from almost 565,000 items to nearly 20 million. Given these striking figures - numbers that, with a few exceptions, only increased over the next 120 years - it seems clear that the post had achieved its goals of providing a reliable, inexpensive service that would, in contrast to the communications of the preceding era, tie the "remote points" of the country together so that the "state of affairs throughout the country be ascertained with ease and quickness, so that all classes may be able to have their letters forwarded with the greatest possible expedition."3

Success was not a given. In its first years the new national postal system in fact had to compete with the Edo-era private courier companies (hikyakuya) that had survived into the Meiji period. To ensure its growth, Maejima Hisoka, the driving spirit behind Japan's new postal system, took initial steps to bring the private couriers under state control in 1871, and finally, having achieved that aim, to ban any private carriage of mail in $1873 .^{4}$ The largest of the Edo-era courier companies vigorously defended their businesses; ultimately, though, through Maejima's direction they played an instrumental role in the early growth of Japan's post through their conversion to a unified corporation whose main role was as a subcontractor to the government, providing carriage of letters and parcels between distribution points. Naturally, then, one cannot account for the success of the Meiji post without some understanding of these companies, their origins, and the nature of communications in the Edo period.

It is tempting to claim today's Nittsū, as the global logistics corporation Nippon Tsūun Kabushiki Kaisha is now commonly rendered, as a lineal descendant of the Riku'un Moto Gaisha, the first Meiji company formed of the surviving major Edo-era couriers. Indeed, that is the narrative development suggested by Nittsū's company history. But the story is not so simple. Nittsū's company history makes clear that it was officially established as Nippon Tsūun Kabushiki Kaisha in 1937 as government-directed, semi-private company under the constraints of war, becoming a fully private company in 1949. This is a demarcation from the 1870s as the Riku'un

\footnotetext{
${ }^{2}$ Richard R. John, Spreading the News: the American Postal System from Franklin to Morse (Cambridge: Harvard University Press, 1995), vii.

${ }^{3}$ Postal figures are from Yabuuchi Yoshikiko, Nihon yübin hattatsu shi (Tokyo: Akashi Shoten, 2000), 223; announcement of goals of new postal service from “A Japanese Post Office," The Japan Weekly Mail, 29 April 1871.

${ }^{4}$ Shashi: Nippon Tsūun Kabushiki Kaisha (Tokyo: Nippon Tsūun Kabushiki Kaisha, 1962), 127-129. Hereafter, Shashi.
} 
Moto Gaisha transformed into the Naikoku Tsūun Kaisha in 1875. This company merged with several others in 1928 to become Kokusai Tsūun Kabushiki Kaisha. ${ }^{5}$

The formation of the Riku'un Moto Gaisha is tied to the leadership of the merchant courier (hikyakuya), Izumiya. By the end of the Edo period, there were but five large private courier companies remaining in Edo. ${ }^{6}$ Perhaps because Izumiya's owner, Yoshimura Jinbei, had already served the Meiji government as an official in a fledgling office of commerce (shōhō kaisho) in 1869, he and his chief managing officer, Sasaki Sōsuke, were approached by Maejima Hisoka in order to convince their fellow private couriers that they would do better to cooperate with the new postal system than to challenge the government for their rights to continue the private conduct of mails. ${ }^{7}$ And so, Izumiya's Yoshimura Jinbei and Sasaki Sōsuke took the lead in reorganizing the couriers - four other great hikyakuya companies as well as multiple affiliated companies in Kyoto and Osaka-into a subcontracting company for the Meiji government postal service.

\section{Nippon Ts un Kabushiki Kaisha's Company History as Documentary Source}

One purpose of this article is to reveal the value of Nittsū's company history in documenting the private couriers. The 1,094-page shashi of Nittsū devotes over 130 pages to the Tokugawa and early-Meiji history of the private couriers. Uno Shūhei, the author of the chapter on the era of the hikyaku, draws on multiple sources, many of which are in the archives of Nittsū and the archives of the former Ministry of Posts and Telecommunications. Kodama Kōta subsequently collected some of these records from other important transporters used in Nittsū's shashi as part of a multi-volume series on early modern Japanese communications.8 An important source for government documents used by Uno is the reference on pre-Meiji transportation Dai Nippon Teikoku ekitei shikō.9 Eschewing footnotes as is often Japanese practice, Uno nonetheless thoroughly documents his sources in the body of the text. As the citations in the following summary of Edo-era communications will show, Nittsū's shashi is an indispensible reference. Because it is meant to connect Nittsū with the past, it focuses almost entirely on the development of courier companies in the largest cities, only hinting at the range of communications structures that developed in other parts of Japan. Nonetheless, for the historian of early modern Japan, it greatly enriches our understanding of the interplay between official and private affairs, the dynamism of Japanese society, and the importance of long-distance communications in the management of government, business, and private matters.

This article also introduces the hikyakuya (sometimes hikyaku), the array of organizations responsible for conducting overland communications, both public and private, in Tokugawa Japan. Originating in the demand for regularized information exchange among the samurai class early in the era, the hikyaku couriers soon began to carry letters, goods, and cash between the cities of Kyoto, Osaka, and Edo. The networks created by these companies (and in some cases government-operated organizations) grew with the commercial economy and came to cover most of Japan. Thus, while there was no "national" network, there was a series of networks that could be linked by cooperating transport companies as circumstances demanded. In the political and economic environment of Tokugawa Japan, the success and survival of hikyaku companies was never a given. They operated under the constraints of a transport infrastructure created first and foremost to meet the needs of the governing military class. They often faced challenges from post station officials and workers, bandits who preyed on travelers, inclement

\footnotetext{
${ }^{5}$ Shashi, 1-3.

${ }^{6}$ Ibid., 128.

${ }^{7}$ Yūseishō, Yūsei hyakunenshi (Tokyo: Yoshikawa Kōbunhan, 1971), 96-97.

${ }^{8}$ Kodama Kōta,ed., Kinsei kōtsū-shi shiryō, vol. 7, Hikyaku kankei shiryō (Tokyo: Yoshikawa Kōbunkan, 1974).

${ }^{9}$ Aoe Shū, ed., Dai Nippon Teikoku ekitei shikō. First edition 1882.
} 
weather, and the growing numbers of people traveling the roads, stretching the resources of the post stations and ferries that provided for them. Finally, the courier companies struggled to balance the search for profit with the need to cooperate with peer organizations (for a time as a trade guild) so that they could effectively negotiate with government officials and post station agents to overcome the various challenges to their businesses. As a side effect of this cooperation, attempts by rivals or upstarts to innovate through streamlined relay practices were squelched as the dominant businesses jealously guarded the clientele that each had developed and nurtured. The largest of these companies survived into the Meiji era and consolidated to form an organization that ultimately became Nippon Tsūun, a twenty-first century global logistics power. Such a development strongly implies the importance of communications for Edo-period society and the role that those involved in it played in laying the stage for Japan's modern communications in the Meiji era and beyond.

\section{Transport Systems in Tokugawa Japan}

Before examining the types of courier arrangements a brief introduction of the general contours of the transport infrastructure, both overland and maritime, will aid in placing the couriers within the larger movement of people and goods. The overland transport infrastructure of the Tokugawa period was based on the five main highways. Two highways joined Edo to the Kyoto-Osaka region. The Tōkaidō extended from Edo to Osaka. It consisted of 58 post stations, six sea crossings and two river crossings. The Nakasendō, stretching from Edo through central Japan to Kyoto, had a total of 79 stations. Other roads included the Ōshū and Nikkō roads extending north from Edo, and the Kōshū highway, which connected Edo to the Nakasendō. ${ }^{10}$ These main highways were connected by many auxiliary roads too numerous to name. The post stations on the highways were allowed tax exemptions and given stipends to offset costs of aiding transporters and travelers. Travelers were required to transfer their cargo at each station as a means both of ensuring business at each station and as a way to alleviate physical burdens on horses and soldiers. ${ }^{11}$

The bulk of cargo that moved between regions of Tokugawa Japan was not carried overland, but rather was shipped by sea. The principal freight carried by boats was tax rice, so Osaka became an important shipping hub with a major part of shipping occurring between Osaka and Edo. The Inland Sea was long an important shipping corridor, connecting Osaka to Kyūshū and from there up the western coast to Hokkaidō. Edo was also linked to the Tōhoku region by shipping along the east and northeastern coasts. ${ }^{12}$ Boats carried more than rice, of course. They carried items such as soybeans, sake, soy sauce, vinegar, dried fish fertilizer, salt, lumber, tatami mats, and many other goods for sale. ${ }^{13}$ But boats were naturally subject to capsizing in storms, and water damage to goods was a constant concern, as was timeliness of shipments. For these reasons, overland transport was preferred for the movement of such things as textiles, cash, and written communications. Transport of these types of goods, and letters in particular, was the business of the hikyaku couriers.

\footnotetext{
${ }^{10}$ Maruyama Yasunari, “Gokaidō to wakikaidō,” in Nihon kōtsūshi ed. Kodama Kōta (Tokyo: Yoshikawa Kōbunkan, 2001 ), 199.

${ }^{11}$ Constantine Vaporis, "Post Station and Assisting Villages: Corvée Labor and Peasant Contention," Monumenta Nipponica, 4 (Winter, 1986): 378-379.

${ }^{12}$ Robert G. Flersham, "Some Aspects of Japan Sea Shipping and Trade in the Tokugawa Period, 1603-1867," Proceedings of the American Philosophical Society 110, no. 3 (June 1966): 182.

${ }^{13}$ Watanabe Nobuo, "Kaijō kōtsū," in Nihon kōtsūshi ed. Kodama Kōta (Tokyo: Yoshikawa Kōbunkan, 2001 ), 235.
} 


\section{Types of Hikyaku}

Japanese scholars usually identify three general categories of hikyaku courier operations. ${ }^{14}$ Tsugibikyaku, or "shogunal couriers," refers to the couriers and the relay system of which they were a part that was operated by the Tokugawa bakufu authorities to communicate official business. Daimyo hikyaku, or "daimyo couriers" similarly refers to both couriers and the systems set in place by the largest domains to conduct communications between the domain and official residences in Edo, Osaka, and Kyoto. Machi-bikyaku- "merchant couriers"-refers to all of the private enterprises that handled letters and freight as their principle business. Among these, the sando-bikyaku ("thrice-monthly") companies of Osaka, the Kyoto junban hikyaku ("rotating dispatch") companies, and the Edo jo-bikyaku ("designated couriers") companies dominated communications between the three major cities as well as providing connections as far north as Hakodate and as far south as Nagasaki. In addition, there were transport companies that were identified with a particular commercial product, such as the chijimi hikyaku of the Echigo region whose main role was to provide transport for crepe textile merchants between Echigo in the northwest and Edo, Kyoto, and Osaka. The kome hikyaku of Osaka specialized in the publication and distribution of reports on the rice market. These companies were similar in character to the merchant couriers (machi-bikyaku) but more specialized in clientele and services provided. Another specialized service was performed by companies belonging to the guild known as the mukumi hikyaku, so called for attachment of these houses to one of six Edo associations. These companies specialized in transport for the daimyō retinue traveling between the home domain and Edo as part of the sankin kötai system of forced residency in Edo. ${ }^{15}$

\section{Shogunal Couriers}

The bakufu's official transport service had its roots in practices developed in the course of the Warring States Period (1467-1568). The various lords who had consolidated control over domains had instituted internal communications systems. These were further absorbed into semi-national systems with the rise to power of Toyotomi Hideyoshi and his lieutenant Tokugawa Ieyasu. By the time Tokugawa Ieyasu's forces vanquished its rivals at Sekigahara in 1600, there was already in place a system of transfer stations for information and material from Edo to the Kansai region (Osaka and Kyoto) and from the Kansai further south to Nagasaki. ${ }^{16}$ The Tokugawa government inherited this structure and refined it over the course of the seventeenth century.

While occasionally carrying small cargo, the shogunal courier's main function was to transmit the documents of the bakufu senior councilors ( $r \bar{j} j \bar{u})$, the Kyoto shoshidai (bakufu deputy), the offices of Osaka and Nijō castles - in short, all of the bakufu offices including intendant offices used this official service for communications with Edo. ${ }^{17}$ Documents were delivered to the tenmajo transport office in a letterbox (jō-bako); the tenmajo runners carried them to the first station in Edo, Shinagawa. From there, in principle, two runners accompanied the box, alternating between the tasks of carrying the box and running ahead to clear the road. At night

\footnotetext{
${ }^{14}$ Fujimura Junichirō, "Tsūshin to hikyaku,” in Taikei Nihonshi sōsho v. 24, Kōtsū, ed. Kodama Kōta (Tokyo: Yamakawa Shuppansha, 1970), 188-192. Also, Fujimura Junichirō, "Jōhō dentatsusha: hikyaku no katsudō,” in Nihon no Kinsei, v. 6, Jōhō to kōtsū, ed. Maruyama Yasunari, (Tokyo: Chūō Kōron, 1992).

${ }^{15}$ Tokugawa leaders developed a formalized system by which daimyo alternated attendance between their home domain and Edo. The system was meant to force daimyo to demonstrate loyalty to the shogun, but it also caused daimyo to expend enormous resources on the transport of their retinues.

${ }^{16}$ Shashi, 30-32.

${ }^{17}$ Fujimura Junichirō, "Tsūshin to hikyaku,” 289-290; and Yūseishō, Yūsei hyakunenshi (Tokyo: Yoshikawa Kōbunkan, 1971 ), 17.
} 
one runner carried a lantern on a pole to help negotiate the road. Records of two stations, Hodogaya near Edo and Moriguchi near Osaka, indicate that letterboxes were often carried by four men, and freight by as many as six. ${ }^{18}$

Each station was to have a tenma yaku or tonya (official overseeing provision of carriers and horses, sometimes read as toiya) and healthy men on duty. By 1640, stations on the Tōkaidō were required to keep 100 men and 100 horses on duty; stations on the Nakasendō and Mino highway, 50 each; and stations on Nikkō, Kōshū, and Ōshū, highways 25 men and horses. ${ }^{19}$ The tonya was often the village headman and was always from an elite family. ${ }^{20}$ At the beginning of the Tokugawa period each station was to receive 50 bales (hyō) of rice to subsidize the duty-free operation. ${ }^{21}$ In practice, stations received different allotments depending on distance to the next transfer and the difficulty of the terrain. For example, Odawara station, lying at the base of the mountains leading west to Hakone, received about eighty-six koku while Shōno and Ishigakushi stations received just over twelve $k o k u{ }^{22}$ In addition, station officials received tax exemptions for their service. Stations found it difficult or impossible to meet their obligations, however, and by the 1630's neighboring villages were being required to provide supplemental horses and men to the post stations. In 1694, these practices were systematized and such villages officially designated as "assisting" villages. ${ }^{23}$

Shogunal couriers were given the highest priority on the roads and in the stations. Kachi metsuke, lower bakufu officers with police functions, investigated any delays or mishandling of these communications. ${ }^{24}$ Investigations were thorough and punishments could be harsh. In 1686 the Hodogaya transport agent was punished by banishment from within $20 \mathrm{ri}$ of Edo (one ri was approximately four kilometers) and the loss of his possessions for incorrectly forwarding a single shipment from the Kyoto deputy (shoshidai) to the Edo senior councilors in two shipments. In 1748, when the Moriguchi station agent failed to attach an explanatory memo to a delayed post, its records for the previous ten years were audited in an investigation that lasted eight months. ${ }^{25}$

It is estimated that the system of stations, post officials, and runners that constituted the Shogunal courier system along the Tōkaidō highway was in place by 1632 or 1633 (Kan'ei 9, 10). ${ }^{26}$ In 1696 the tenmajo transport office reported to the Edo city commissioner (machi bugyō) that express deliveries between Edo and Kyoto took sixty-four to sixty-six hours, or just under three days and that special express deliveries had been made in sixty hours. Another report only four years later indicated that express mail required eighty-two hours (about three and a half days), and normal mail was delivered in ninety hours (just under four days). However, a special class (mukoku, or "no time") could be delivered in as little as fifty-six hours (just over two days). By 1763 time for the delivery of official documents from Kyoto to Edo were set at five days for normal mail, four days for express, and sixty-eight hours for special express mail. ${ }^{27}$ Of course, the above delivery times were based on optimal conditions.

\footnotetext{
${ }^{18}$ Yabuuchi Yoshihiko, Nihon yūbin sōgyōshi: hikyaku kara yūbin e, (Tokyo: Yuzankaku, 1975), 30-31. Yabuuchi does not speculate on the discrepancy, only noting that no documents have been found to explain the need for more than two runners. It may have been for security purposes as the roads east of Hakone and around Moriguchi were notorious for bands of thieves.

${ }^{19}$ Kodama Kōta, Shukueki, (Tokyo: Shinshusha, 1963), 45-46.

${ }^{20}$ Yüsei hyakunenshi, 16-17.

${ }^{21}$ Shashi, 31. According to Yabuuchi, stations might be paid in rice or cash, or a combination of the both, 27.

${ }^{22}$ Yabuuchi, Nihon yūbin sōgyōshi: hikyaku kara yūbin e, 27. Koku was a standard rice measurement, approximately five bushels.

${ }^{23}$ Vaporis, "Post Station and Assisting Villages: Corvée Labor and Peasant Contention," 384.

${ }^{24}$ Yüsei hyakunenshi, 17.

${ }^{25}$ Yabuuchi, 30.

${ }^{26}$ Shashi, 32.

${ }^{27}$ Yūsei hyakunenshi, 17-18.
} 


\section{Daimyo- Couriers}

Each domain had in place its own internal system of communications. ${ }^{28}$ In addition, many domains connected their internal communications to Edo by placing their own runners at points along the main highways. These latter were known generally as daimyō hikyaku and sometimes specifically as shichi-ri hikyaku.

The logistics of alternate attendance in Edo, the need to convert tax rice to cash in Osaka, and relations with the Imperial Court in Kyoto required many domains to maintain residences and offices in the three major cities. For efficient governance, domain leaders needed ready access to information from these three great urban centers; they also needed to convey information within the domain itself. Tottori domain, for example, operated a courier system placing an officer in charge of communications both in Tottori and in Edo (hikyaku gashira). While these operated for the purpose of carrying official letters, domain samurai were allowed to post private letters into official boxes and could expect their letters to reach home in about ten days. The system seems to have been widely used, for the domain frequently issued orders that all communications be written on the lightest paper available and that only official letters would be accepted. Tottori domain also sent low-ranking samurai messengers at intervals en route during the sankin kotai procession to all of its domainal offices and residences to apprise them of the daimyo's safety. ${ }^{29}$ Tottori maintained an extensive communications system of village relays (mura okuri) within the domain as well. The couriers of this system were commoners performing corvée. By 1856 there were relay stations set up throughout the domain, insuring almost daily communications between the castle town and other domain cities and villages. ${ }^{30}$

The most famous of the daimyo hikyaku were the "seven-ri" couriers (shichi-ri hikyaku) of Owari and Kii domains (though others such as Mito, Echizen, Izumo, Himeji, Tsuyama, Takamatsu, and Kawagoe also maintained similar systems at various times). ${ }^{31}$ The term shichi-ri hikyaku is often thought to refer to the distance between transfer stations on the routes set up-approximately one every seven ri. In fact, the eighteen transfer stations of Owari, for example, were placed on average at just over four $r i$ (that is, about every ten miles). ${ }^{32}$ The couriers were usually low-ranking samurai (ashigaru) or commoner servants (chīgen). Owari, for example, rented a building at each station and had two domain agents per station conducting business. ${ }^{33}$

The Kii official daimyō hikyaku couriers, who, like the Owari couriers were either low-ranking samurai or commoner servants, held a place in the popular imagination. Though low ranking in status, those who were strong, literate, and able to speak "officialese" with some fluency were selected to be transport office managers at one of the thirteen stations between Wakayama and Edo. They wore jackets fashioned with fierce dragon and tiger designs. They also carried swords and jitte, a metal rod used for capturing criminals. More than just managers arranging carriers, their duties included aiding the daimyō procession on alternate attendance, forwarding advance notice of the arrival of officials to stations to ensure that rooms for overnight stays and men and horses for transport were available, providing aid for difficult river and mountain crossings, reporting on natural disasters and transportation delays, and monitoring the roads branching off the main highways. ${ }^{34}$ In keeping with their police-like role, they were said to be notoriously domineering. ${ }^{35}$

\footnotetext{
${ }^{28}$ Ninomiya Hisashi, Nihon no hikyaku-bin, (Osaka: Nihon Fuiraterikku Senta, 1987), 33. These systems were known variously as ichi-ri tsugi, mura tsugi, or mura okuri - all indicating a village-to-village relay system that could be used by village headmen in official communications.

${ }^{29}$ Fujimura, Nihon no Kinsei, 315.

${ }^{30}$ Ibid., 316.

${ }^{31}$ Shashi, 32-33; Yūsei hyakunenshi, 18.

${ }^{32}$ Ibid., 33.

${ }^{33}$ Fujimura Junichirō, "Tōkaidō Bishū shichiri hikyaku ni tsuite," Nihon Rekishi 475 (December 1987): 4.

${ }^{34}$ Fujimura, Nihon no Kinsei, 316-317.

${ }^{35}$ Ibid., 318.
} 


\section{The Emergence of Private Merchant Transporters}

The courier system was in many cases a burden to the station in which the shichi-ri office was located. That station had to supply the runners or pay fees to acquire runners; managers in most cases did not carry letters or cargo themselves. ${ }^{36}$ The managers enjoyed considerable authority. In response to an investigation by the superintendent of transportation for the Tokugawa bakufu in 1843, the leaders of Futagawa station complained that the Owari shichi-ri agents demanded that runners be on duty to use at their pleasure without payment, that the village provide food and drink, and noted that the Owari agents rode in palanquins and stayed in inns free of charge. They put at risk, the village leaders reported, the continued existence of the station. A letter written just a month later repeated the claims and noted again with emphasis the evils brought about when shichi-ri managers gathered large groups (including vagrants) into the shichi-ri office for gambling. ${ }^{37}$ These abuses were hardly isolated. The village officials of Hodogaya had reported many of the same problems in $1777 .^{38}$

The example of Owari demonstrates the difficulty in maintaining distinctions between official and commercial transportation. According to one report, in 1788, acting on rumors that merchants were abusing the special transport privileges for cheap or duty-free transport given to official cargo, bakufu officials called for the investigation of the Owari shichi-ri couriers. The investigation found that almost fifty crates of cargo entered Edo each month from Owari, but the amount of official documents and cargo included was nil. Merchants had been bribing transport managers to include commercial items. For a time thereafter, Owari was restricted to just five or six crates. $^{39}$

By 1663 there were four commoner-operated courier houses in Osaka, three in Kyoto, and seven in Edo transporting goods between the three major cities of the Edo era. ${ }^{40}$ Most accounts trace the origins of these houses to the needs generated by the logistics of the Tokugawa bakufu. After finally consolidating its power with victories over the forces loyal to the heirs of Toyotomi Hideyoshi in Osaka (1615), Tokugawa officials assumed offices in Osaka Castle and Kyoto's Nijō Castle. Although the bakufu had an official service for important goods and documents, officials in posts in Osaka and Kyoko were left to contrive their own means for communicating privately with family and others in Edo. The account from the official Meiji history of communications details the origins as follows:

In [Genna 1 (1615)] the officials on duty in Osaka Castle conducted talks with the transport officials at all of the stations along the Tōkaidō highway and began sending their subordinates three times per month on the days with 'eight' [i.e. 8, 18th, 28th] to Edo and back. From this came the name sando bikyaku [thrice-monthly courier] and was the source of the interurban houses. Osaka merchants thereafter copied this system, making of it a [commoner] business; they operated under the guise of Osaka Castle servant, wearing the [low-ranking samurai's] happi jacket and carrying two swords. By doing so, they avoided thieves on the roads. ${ }^{41}$

In other words, at some point after 1615 Osaka merchants took over the delivery of officials' personal mails, passing themselves off as low-ranking samurai and in the process gaining access to horses at reduced official

\footnotetext{
${ }^{36}$ Fujimura, "Tsūshin to hikyaku," 292.

${ }^{37}$ Komonjo ni miru Edo jidai no Futagawa-juku, in Futagawa-juku sōgō chōsa: bunken shiryō hen, edited by Watanabe Kazutoshi (Toyohashishi: Toyohashi-shi Kyōikuiinkai, 1999), the investigation cited is Doc. 61, p. 208; the letter is Doc. 63, p. 222.

${ }^{38}$ Fujimura, "Tōkaidō Bishū shichiri hikyaku ni tsuite," 3.

${ }^{39}$ Fujimura cites the travel account of Nakayama Ichinoshin from his Kōkan sensei tōyū manroku in "Tōkaidō Bishū shichiri hikyaku ni tsuite," 4.

${ }^{40}$ Hirooka Haruya, "Hikyakushō ni kansuru oboegaki: riku’un moto kaisha no keifu," Unyu to keizai 17 (April 1957): 38. Also,Yabuuchi, 33.

${ }^{41}$ Dai Nippon Teikoku ekitei shikō, ed. Aoe Shū (Tokyo: 1928 ed.), 143-144.
} 
rates. ${ }^{42}$ Safety on the open road was surely a concern, but swords also gave to the commoner couriers an air of authority within the stations. Furthermore, the former Osaka official couriers had obtained the right to three horses at each station. The merchants, under their "official," guise, continued to enjoy this right. Customarily, the hikyaku courier would ride one horse carrying letterboxes under official seal; the other two horses could be loaded with commercial goods. ${ }^{43}$ Finally, though it is unclear when all Osaka and Kyoto "thrice-monthly" duties were taken over by private merchants, by 1639 the non-official couriers were openly operating the sando-bikyaku. ${ }^{44}$

In the early years of the Tokugawa period the commercial centers of Osaka and Kyoto supplied much of the goods needed for Edo's development. Merchants, including those who took over the private Osaka and Kyoto officials' mails, began carrying correspondence on a regular basis for commoners as well. If the records of the couriers that survived into the latter part of the Tokugawa period are accurate, the largest companies had seemingly humble beginnings:

According to tradition, the Osaka couriers listed above [here omitted] little by little arrived in Edo [setting up shop in the locations given above] where they would place a mat on the ground in front of the shop and place the items posted [from Osaka and Kyoto]. People gathering there would pick up items addressed to them, make inquiries into and arrange for the next dispatch for Osaka and Kyoto, and return with their post. [Based on the time it took to travel] the couriers were called jo roku, or six-day couriers. Adding in the day of delivery to the courier, it took seven days, and later eight. Izumiya and Osakaya were tofu and vegetable merchants; Bizenya dealt in teacups. They expanded little by little, and at some point their sole business became transport. ${ }^{45}$

From the beginning commerce and communications were closely connected. Those who would be expecting letters were most likely themselves transplanted merchants or subordinates on business from the Osaka and Kyoto region.

Indicative, too, of this growing connection between the needs of commerce and the growth of communications specialists was the emergence of the Osaka "thrice-monthly" courier houses as officially recognized companies. ${ }^{46}$ In 1663 the Osaka couriers who had been transporting for the Osaka Castle officials wearing the happi jackets of low-ranking foot soldiers and wearing swords, banded together to specialize in both commercial and official transport. ${ }^{47}$ They officially gave up the use of the names Osaka and Nijo Castle couriers the following year (1664), becoming recognized as "townsman" courier companies. Certainly, this move was spurred by the growing commercial economy.

Working in cooperation with couriers in Kyoto and Edo, the Osaka couriers took steps toward independence from their ambiguous role as Osaka Castle and Nijo Castle couriers in 1664. The couriers signed a yearly agreement with the Osaka and Kyoto bakufu offices to continue carrying officials' private correspondence as before. For this they were given the right to three horses at stations (three or six, depending on the source). Tradition held that official correspondence would be placed in a box with the Osaka Castle magistrate's seal and attached to the manager's horse; the other two horses could be laden with merchant goods and letters. The Kyoto couriers

\footnotetext{
${ }^{42}$ Yabuuchi Yoshihiko, "Kinsei kōtsū-tsūshin no tokushitsu ni tsuite: Tōkaidō shukueki ni okeru shojō teisō wo chūshin ni," Rekishi Hyōron 141 (May 1962): 50.

43 Shashi,36.

${ }^{44}$ Ibid., 37.

45 Ibid., 38

${ }^{46}$ A fictionalized sando bikyaku ("thrice-monthly" couriers) house, the Kameya, provided much of the setting for one of Chikamatsu Monzaemon's major plays, Meido no hikyaku (The Courier for Hell; first performed in 1711). Chikamatsu Monzaemon, The Courier for Hell, Major Plays of Chikamatsu, trans. Donald Keene (New York: Columbia University Press, 1990), 162.

${ }^{47}$ Dai Nippon Teikoku ekitei shikō, 142; hereafter, Ekitei shikō.
} 
handling Nijō Castle goods and letters carried a placard $(e f u)$ with the Nijō seal. ${ }^{48}$ Based on what was then judged to be the normal travel time between the western cities and Edo, they named their service the "guaranteed six-day mail" service, or $j \bar{o}$ roku. ${ }^{49}$

There were two Osaka groups, one of five houses and one of four, operating on the "thrice-monthly" principle. Contemporary guidebooks from 1679 describe the group of five as the "main courier" (hon-bikyaku) who originally took orders from Osaka Castle. Between the two groups there were at least eighteen shipments per month out of Osaka. ${ }^{50}$ In a testament to the growing needs for quick communications, bans on night travel, instituted in 1639, were lifted for at least the Osaka sando-bikyaku couriers in 1712 with the proviso that they must have a written permit from Osaka and Sunpu (Shizuoka) Castle officials. ${ }^{51}$ In fact, the reforms may have been a nod to reality. A separate source states that (in the years preceding 1712) the Kyoto, Osaka, and Sunpu couriers had been traveling at night (against regulations) and engaging in lawless behavior (furachi). Therefore night travel would be regulated by special permission from the Castle authorities. ${ }^{52}$

Merchants in the Kyoto-Ōmi region had extensive networks and had long been involved in transport. In keeping with its place as the political and cultural center of Japan, various courier routes existed between Kyoto and Osaka, Nara, Ōtsu, Tanba, Echizen, Nagasaki, Kaga, Ise, Himeji, Tsuruga, and Minō. ${ }^{53}$ The Kyoto Deputy (shoshidai) in 1619 charged bashaku (livery agents) with the job of supplying men and horses for the bakufu relay system on roads around Kyoto. ${ }^{54}$ By 1632 they were supplying only porters. ${ }^{55}$ Although positioned to expand their range, it seems that the traditional transport managers of the Kyoto capital did not develop into largescale operations with partnerships in the other metropolises. Though some of the bashaku were involved in developing long distance transport, this role seems to have been filled by merchants. ${ }^{56}$ These came to be known officially as the Kyoto junban hikyaku.

With the establishment of bakufu offices in Nijō Castle in Kyoto, private communications were transported between Kyoto and Osaka and Edo, first by foot soldiers, then by merchants acting as foot soldiers, and finally by merchants who had come into their own in the business of transport. Little is known about the early relations between the Kyoto transporters and the Nijō officials. The first recognition of the relations came much later when the Kyoto city commissioner, noting that the Kyoto couriers' shipments were sent at irregular intervals, often avoiding inclement weather, organized sixteen houses into a guild. The following, from an Edo house, Kizuya, records the origins of the junban hikyaku from the first article of an appeal by those Kyoto houses in 1750:

Concerning the guild of Kyoto couriers, until fifty-three years ago, the couriers undertook business each according to its own convenience. Because the couriers wouldn't send shipments when there were too few parcels, inclement weather, or impassable rivers, it became a hindrance to [the Kyoto authorities'] business. Thus, fifty-two years ago in the seventh month of Genroku 7 (1694) the Kyoto city commissioners Ando (Tsugiyuki) Suruga no kami and Mizuno (Masanao) Bizen no kami ordered all the couriers to the commissioners' office and after investigation named sixteen houses that would thereafter by arrangement dispatch a shipment every night in order without neglect so that official business would not be hindered. In this regard, [the couriers] were put into the junban [rotating duty] guild and its members' numbers registered. Accordingly, a nightly supervising house is designated,

\footnotetext{
${ }^{48}$ Shashi, 43 .

${ }^{49}$ Ekitei shikō, 183. Rare was the delivery that actually made the trip in six days.

${ }^{50}$ Shashi, 43 .

${ }^{51}$ Ekitei shikō, ban on night travel. p. 168; permitted night travel, p. 220.

${ }^{52}$ Koji ruien, Hosokawa Junichirō, ed., (Tokyo: Jingu Shicho, 1896), vol. 19, p. 1329.

${ }^{53}$ Hirooka Haruya, "Hikyakushō ni kansuru oboegaki: riku'un moto kaisha no keifu," 36.

${ }^{54}$ Koji ruien, vol. 19, p. 1328.

${ }^{55}$ Shashi, 31.

${ }^{56}$ Fujimura Junichirō, “Kinsei chūki Kyoto junban-bikyaku doiya no kenkyū,” Shigaku zasshi 74 (November 1965): 60.
} 
and 5, 6, 7, or 8-day dispatches are variously shipped. The cooperating house in Edo is Jüshichiya Magobei of the second block of the Muromachi neighborhood, and [we] will perform our duties both to and from Edo without neglect. $^{57}$

Thus, in principle, sixteen Kyoto courier houses worked in conjunction with a single major Edo transport company, the Jūshichiya ("Seventeen" company). ${ }^{58}$ They conducted round trip carriage of items such as clothing for the shogun, daimyo houses, and temples and shrines. They also handled official mail for Kyoto nobles and Nijō officials, as well as for commissioners and intendants in surrounding bakufu-controlled administrative districts. Included with the above were commercial items for merchant houses. ${ }^{59}$

The political and economic character of the three major cities seems to have shaped the character of communications to, from, and within each of them. Kyoto, as a major producer of silk textiles and clothing, had many transport companies that bypassed Edo, instead establishing trade routes with regions producing raw silk and other textiles such as Fujioka and Fukushima. ${ }^{60}$ By raw count, there were 43 courier houses in 1745 ; by 1810 there were $35 .^{61}$ While this does not say anything about the volume of correspondence and cargo going in and out of Kyoto, it does speak to the tenuous nature of the transport business. The Kyoto guild seemed to be at a competitive disadvantage at stations on the road, finding that recognition from the Kyoto city commissioner was not the same as recognition from the shogunate itself. ${ }^{62}$ In the course of working in conjunction with other houses, financially weaker houses sometimes found themselves operating in name only, their debt held by the larger partner.

By the beginning of the Meiji era, several of the Edo courier houses had such extensive networks of regional offices that they were able to compete for a time with the newly established national postal service. The historical record favors the Edo houses: their house records provide much of the existing data on early modern communications organization. But as the above suggests, Kyoto and Osaka merchants who carried goods and letters themselves between the eastern and western cities originally started most of the big houses, and it was between these houses - west and east - that cooperative relationships were established. Nevertheless, by the second half of the Tokugawa period Edo was no longer primarily a "consumer" city, but also a producer of goods and culture in its own right. While the Edo couriers were the last to effectively organize a guild, they came to hold a position of prominence among the couriers of the three cities.

By the latter half of the seventeenth century merchant houses were specializing in communications, sending managers (sairyō), often with symbols of official authority, to arrange the relay of freight to packhorses along the way. Many of these courier houses developed through connections with textile merchants. ${ }^{63}$ Given the concentration of cotton textile merchants in Ōdenmachō transport area of Edo, perhaps it was natural that these merchants would develop transport operations of their own. A branch house (Shimaya Zaemon) of a wealthy Osaka merchant house with ties to the area began to specialize in transport for cotton merchants in 1671. Later, a group of 12 houses joined together to cater to the needs of cotton goods merchants in Edo and Osaka, creating a kaisho (a central transport office used by all members) in both cities. In Edo the center of activities moved from Ōdenmachō

\footnotetext{
57 “Jō-bikyaku hattan kyūki,” Kinsei kōtsū-shi shiryō, vol. 7, Hikyaku kankei shiryō, ed. Kodama Kōta (Tokyo: Yoshikawa Kōbunkan, 1974), 470-471. This document purports to be a house history of the Kizuya written in 1840 based on the various records handed down by that house. It seems to provide the basis for the general accounts found elsewhere in sources such as Shashi (p. 45, in this account Mizuno Masanao is given as "Echizen no kami").

${ }^{58}$ The name "Jüshichiya" apparently derives from wordplay. The moon of the $17^{\text {th }}$ night-jushichi (17) ya (night)--of the eighth month in the lunar calendar was called "tachimachitsuki," which is a homophone for "instant arrival." So dominant was Jüshichiya — at one time- that its name became synonymous for the term "hikyaku" (courier). Nihon kokugo daijiten, (Tokyo: Shogakukan, 1974), vol. 10, p. 258.

${ }^{59}$ Shashi, 45.

${ }^{60}$ Fujimura, Nihon no Kinsei, 298

${ }^{61}$ Fujimura, "Kinsei chūki Kyoto junban-bikyaku doiya no kenkyū," 59.

${ }^{62}$ Shashi, 46.

${ }^{63}$ Hayashi Reiko, Nihon no rekishi (Tokyo: 1992), vol. 5, Shōnin no katsudō, 98.
} 
to Setomonochō in 1701. The operation was overseen by the Shimaya Sōemon house, which became one of the major overland transporters throughout the Edo period. Significant activity by Edo-based couriers thus began in the commercially and culturally vibrant Genroku-Hō'ei era (1688-1710). ${ }^{64}$

In addition to goods, Edo transporters specialized in carrying cash, and advertised their services under the name "cash couriers" (kane-bikyaku). They were also known as te-ita kane-bikyaku for their development of a system of cash transfers using a kind of registered mail with stamped receipts. ${ }^{65}$ Considering Chikamatsu's use of cash shipments as a recognizable plot device in his play The Courier for Hell in 1711, the couriers who dealt in such a business must have been commonplace by the end of the Hō'ei era. ${ }^{66}$

The years of early growth were years of economic upheaval for the bakufu and various domain governments. In the wake of fiscal instability and famine, the eighth shogun Tokugawa Yoshimune (1684-1751) instituted a series of measures commonly known as the Kyōhō reforms (known as such for the Kyōhō era-1716 to 1735 - in which they were instituted). Generally speaking, Yoshimune attempted to shrink government spending while encouraging development of taxable rice land. In shrinking government spending, he also cut back on government-operated transportation (as did domains such as Owari, which suspended domain courier operations). For the private courier houses this was a boom era of growth and competition.

\section{Toward Transport Guilds: Structural Constraints on Communications}

Communications between Edo, Osaka, and Kyoto came to be dominated by a select number of private businesses by the late seventeenth century. Nonetheless, these hikyaku transporters only enjoyed limited official privilege. As seen above, the Kyoto companies had official backing from the Kyoto city commissioner, but the authority of that office was ambiguous at post stations along the five main highways. Other major companies had cultivated ties with individual domains, but this alone was insufficient to ensure survival. Still, the largest houses had in effect begun to behave as a trade association, fending off competition through cooperative tactics.

The competition among transporters began to intensify from the early eighteenth century, and this competition had the potential to revolutionize the nature of communications in the Tokugawa era through the introduction of high-speed relay transport. Around 1707, a mukumi transport company, Wakasaya (Wakasaya Chūemon), began cultivating clients along the Tōkaidō by operating a runner system (kachi hikyaku). ${ }^{67}$ In 1719 , Wakasaya Chūemon established eighteen independently operated horse transfer stations along the Tōkaidō between Shinagawa and Osaka and began express service. Freed from the need to await horses at the post station facilities used by other courier houses, Wakasaya Chūemon's express business began to attract clients away from the established "thrice-monthly" group that had dominated communications. ${ }^{68}$ Around this time (though the exact dates are not clear) former employees from three "thrice-monthly" companies began operations on the Wakasaya model. When opportunity presented itself the established "thrice-monthly" houses joined ranks to petition for the prohibition of these independent operations. ${ }^{69}$ In 1743, an express courier for Wakasaya had letters containing cash stolen from him. Because express couriers were particularly vulnerable to robbery, they were prohibited from

\footnotetext{
${ }^{64}$ Shashi, 47-48.

65 "Shimaya Sōemon kasei roku," in Kinsei kōtsū-shi shiryō, vol. 7, Hikyaku kankei shiryō, ed. Kodama Kōta (Tokyo: Yoshikawa Kōbunkan, 1974), 3-4. One stamped paper (te-ita) followed the shipment and another was kept at the courier office; the remittee's stamped proof of receipt would be forwarded back to the couriers' offices.

${ }^{66}$ See note 36 .

${ }^{67}$ Ekitei shikō, 226.

${ }^{68}$ The service was expensive: a three and a half day post was over 8 ryō, a four-day delivery cost just over 6 ryō. Ibid., 255 .

${ }^{69}$ Yabuuchi, 36-37. Shashi, 51-53.
} 
carrying cash. As a result of their petition, the Edo city commissioners' office issued a ban on these relatively new express operations in $1744 .^{70}$ As a compromise, if determined that express letters faced delay along the roads, the road foreman was allowed at any post station to separate those letters and forward them ahead of the normal cargo by hiring runners for the purpose $(\text { nuki jo })^{71}$

In order to protect themselves and to limit competition the "thrice-monthly" carriers formed a quasiguild. Under the direction of Ōsakaya Mohei house, it set down a list of regulations (sadamegaki) in 1741 for its members to follow. Most noticeably, the agreement set down principles for the management of express mails. All were to be forwarded to a special office, the haya kaisho, and sent under the direction of Ōsakaya using the eighteen relay stations established by his "former" employee Kyūjirō, one of the upstarts mentioned above. ${ }^{72}$ This was, in effect, a power move on the part of Ōsakaya Mohei, facilitated by a favorable ruling in a case brought by Kyoto carriers against the Edo carriers two years earlier (the preamble to the regulations states that the ruling gave Ōsakaya Mohei the duty to set down the principles for the group).

An increasingly commercialized economy in the eighteenth century pushed the demand for more overland transport and faster communications. It was under these circumstances that the communications specialists in Edo, Osaka, and Kyoto sought at the same time greater integration and protection while trying to develop new markets in the hinterland. Meanwhile, social dislocations seem to have resulted in large numbers of vagrants and bandits infesting even the most-traveled highways, creating greater need for government protection and intervention in matters of transport and communication. By the 1770 s, conditions on the roads and at post stations had worsened considerably. This petition from 1773.11 lays out the problems facing the transporters and the measures they hoped the bakufu would take on their behalf:

\section{We humbly present the following request:}

Item: The nine [Edo] houses together humbly make this entreaty. We have been transporting on behalf of the bakufu, its intendants, and the various lords, as well as providing for the private correspondence of samurai and the business correspondence of merchants since the Kan'ei era (1624-1643). We have received the official seals of Osaka and Nijo castles. In the beginning a normal mail took 8 to 9 days [between that region and Edo]; an express delivery took 5 to 6 days. Nowadays, however, there are few horses, so we are temporarily detained at the post stations. Currently, even if there are no obstructions at the rivers we may still wait up to 15 days to cross. An express letter now takes 7 to 8 days, and a normal post takes as much as 20 to 30 days. Because of these delays, the urgent business of bakufu intendants, officials, and even townsmen is being transmitted by their own servants. Our business is dwindling and we are forced to send normal mails as express at great loss. Duty-free cargo sent under official seal naturally causes hardship at the stations, which try to make up the losses. We must pay fees in addition to the standard fees at each station. Moreover, we hear reports that along the roads, the grooms stop the horses and extort exorbitant "tips." In this regard, we ask that yearly orders be issued so that along the Tōkaidō all hikyaku goods be expedited in the same manner as goods under official seal at all post stations and at river crossings. The

\footnotetext{
${ }^{70}$ Shashi, 53.

71 “Jō-bikyaku hattan kyū ki," Kinsei kōtsū-shi shiryō, vol. 7, Hikyaku kankei shiryō, ed. Kodama Kōta (Tokyo: Yoshikawa Kōbunkan, 1974), 483. Interestingly, at nearly the same time (1660) in London William Dockwra began a private penny post to fill a gap in the service of the Royal Post. Until that time there had been no metropolitan service. Letters had to be picked up in person from the general post office. Though not in competition with the Royal post, which did not serve Londoners directly anyway, Dockwra's popular service was perceived as a potential threat to the Duke of York, into whose coffers flowed revenue from the post. Dockwra's efficient service was banned, but it did lead the post to initiate improvements in urban service. But as with Japan, "improvement lagged behind public demand." Howard Robinson, The British Post Office: a History, (Princeton: Princeton University Press, 1948), 69.

72 "Jō-bikyaku hattan kyū ki," Kinsei kōtsū-shi shiryō, vol. 7, 477-482. The house was known legally as Ōsakaya Mohei, though the comtemporary Mohei was yet in minority. His affairs were looked after by two others, Kan'emon and Heibei.
} 
couriers will refrain from rude behavior and will pay all fees as has been the custom. We pledge to an annual gratuity [myōgakin] of fifty ryō per member. ${ }^{73}$

This appeal makes clear the contradictions in a transport system designed for military priorities but used predominantly for the transport of commercial goods. It also points to a growing problem of lawlessness in certain areas. $^{74}$ Authorities appear to have had little inclination to impose reforms that might have reorganized communications more efficiently. For their part, transporters sought whatever protections and guarantees available under the Tokugawa political order. The unique political and economic conditions of the Tenmei period did much to strengthen the resolve of the commercial transporters to band together as an officially recognized guild in order to obtain privilege at stations and protection from encroachments by outside competitors.

Edo commercial couriers had periodically petitioned for official guild status since 1741 . In the 1773 appeal, the pledge to submit 50 ryō in exchange for aid in expediting transfers at stations, crossings at rivers, and ending illegal practices by porters and vagrants is indicative of the Edo carriers' intentions. It was not until 1782, though, that they achieved their goal. That they became an officially licensed organization is perhaps not surprising; the years in which the Senior Councilor Tanuma Okitsugu exercised influence over bakufu efforts toward financial solvency (1767-1786) are remarkable for the rise of licensed merchant guilds. ${ }^{75}$ Unclear, however, is why the bakufu was slow in granting guild status to the transport companies.

The nine merchant houses that made up the Edo official carriers guild agreed to pay 100 ryo each in the inaugural year of the guild and $50 r y \bar{o}$ per year thereafter. In exchange, they were allowed to use the word "designated" $(j \bar{o})$ and were called thereafter $j \bar{o}$-bikyaku. The bakufu was to send notice to stations that they were to handle jo-bikyaku freight as they would bakufu or daimyo official cargo and letters such that a transport manager with the jō-bikyaku seal could expect his freight to be transferred to the first available horses in the order that it arrived at a station. ${ }^{76}$

By the time these main merchant carriers had gained their long sought-after status, the character of the houses and their interrelations had changed. Many of the original petitioners from the 1740 s were dead or retired. In the absence of the certainties that guild membership was presumably to ensure, most of the Edo merchant carriers had cultivated exclusive relations with powerful domains as official domain carriers. Shimaya, for example, was aligned with Mito, Jūshichiya with the officials of Kyoto's Nijō Castle, Izumiya with the officials at Osaka Castle, and Ōsakaya with Kii domain. ${ }^{77}$

The two decades of the 1770s and 1780s were a time of repeated natural calamity for Japan, and this too had repercussions for the transport business. The eruption of Mount Asama in the northern Kanto region in 1783 coupled with widespread crop failure that year caused thousands of deaths, particularly in northeastern Japan (Tōhoku). Crop failure in 1786 left yields at only one-third the yearly average, spreading famine and disease

\footnotetext{
73 “Jō-bikyaku hattan kyū ki," Kinsei kōtsū-shi shiryō, vol. 7, 487-489.

${ }^{74}$ The records of the mukumi carriers contained in Kinsei kōtsū shiryō-shū, hikyaku kankei shiryo identify banditry and extortion as two continuing worries for the members of this guild. The area between Odawara and Edo, according to the records, was rife with groups that either threatened violence at stations if money was not "loaned," or outright robbed the couriers, "Mukumi hikyakuya kyūki," 66 and passim.

75 John W. Hall, Tanuma Okitsugu, 1719-1788: Forerunner of Modern Japan, Harvard-Yenching Institute Monograph Series (Cambridge: Harvard University Press, 1955), 80. According to Hall, "[b]y 1780 Edo and Osaka each had over a hundred such associations.... All of these organizations paid to the government a yearly tax (unjō or myōga). Although there was little uniformity in the rate of assessment, and few merchants were taxed systematically according to what they were able to pay, by mid-Tokugawa period the shogunate was adding appreciably to its income through this method of extracting revenue from the merchants."

${ }^{76}$ “Jō-bikyaku tonya negai-zumi ikken," Kinsei kōtsū-shi shiryō, vol. 7, 497-498.

${ }^{77}$ Shashi, 76.
} 
throughout the country.78 A characteristic of pre-industrial overland transport is its reliance on food sources for fuel. The Shimaya house noted in its records in Tenmei 6 (1786) that along the Tōkaido the soybeans for horses had become expensive, the horses were sick, and the men suffering.79 Calculating the needs of soybeans and rice bran per horse, Shimaya contributed just over 405 ryō in gold and over six kan in silver for 4, 404 horses on both the Tōkaidō and Nakasendō highways; it also contributed funds to agents and others at stations with which it did business. ${ }^{80}$ Shimaya was positioned to weather the continued disasters, though. At that time it boasted of having a staff of 597 men and women across its network of offices. ${ }^{81}$

All of the nine Edo merchant carriers maintained relations with domains as official carriers. In this capacity, they were given the right to transport letters and freight under an official seal, which in many cases was affixed to a wooden placard (efu) accompanying the cargo. The placard alerted station transport officials that such cargo should be carried at a fixed low rate. The practice of granting duty-free or low-rate carriage to official (i.e. bakufu or domain) cargo was a strain on station finances in the best of times, but by the late eighteenth century it became a major source of contention between the station agents who sought to offset loses by high rates on travelers and commercial cargo and merchant carriers who sought any means available to reduce costs and hasten transfers at stations. $^{82}$

Wielding symbols of authority in order to gain advantage at stations was hardly a new practice. The first Edo-era courier services operated under official title as couriers for Osaka and Nijō Castles. Merchant carriers went to great lengths to gain the privilege of using official symbols. For example, a carrier originally based in Kyoto, the Inokuchiya, gained the right to use the seal of Owari domain as a purveyor of services, but continued throughout the years of its service to petition for the right to bear swords. In 1736, a Niigata carrier was executed when his agent, who was shipping commercial goods, was discovered at Araima station on the Nakasendō highway using a counterfeit placard and illegally carrying swords. The merchant carrier's head was sent back to Araima from Edo for display as a warning against fraudulent use of official seal and swords. ${ }^{83}$ It was in this atmosphere of increasing lawlessness on the roads and abuse of official privilege that an order banning the transport of excess cargo at night and the mixing of official and private letters and goods was issued in $1747 .{ }^{84}$ Bakufu and other official documents and cargo received first priority at stations. Not only was carriage free (or in some cases at guaranteed low fares), but also it was processed through stations before private cargo. Gaining equivalent treatment was a matter of business survival for the merchant houses.

Bakufu measures taken to curb abuses were not applied universally, however. For example, merchants from the Ōmi region near Kyoto had long-established business networks with towns and cities in the northern Kantō and the Tōhoku region (principally Fukushima, Yamagata, and Sendai). At first they concentrated on buying and selling silk thread and finished textiles, but as business increased they began to transport cargo as well. In 1725, Ōmi Hachiman merchants, who had already begun to assume the character of hikyaku, gained the right to use the official seal of the Sendai daimyo Ishikawa Yamato-no-kami and to bear swords. Later, after acting as transport agents for court noble Reizei Chūnagon and the Reizei princess to Sendai, the Ōmi Hachiman carriers returned the Sendai seal and became known as the Reizei group, and their cargo Reizei freight. One record of 1753 claimed that the "cargo of Hachirō'e [Hachiman hikyaku] was sent through the stations without ever even touching the ground." 85 Of course,

\footnotetext{
${ }^{78}$ Hall, 122.

79 "Shimaya Sōemon kasei roku," Kinsei kōtsū-shi shiryō, vol. 7, 50.

${ }^{80}$ Shashi, 80 .

${ }^{81}$ Ibid., 80 .

${ }^{82}$ The contention between stations and carriers over petitions for rate increases by the former and abuse of official placards was a recurrent theme in hikyaku documents; a particularly good example can be found in "Efu nimotsu ōtai ikken," in Kinsei kōtsü-shi shiryō, vol. 7, 227-291.

${ }^{83}$ Shashi, 67.

${ }^{84}$ Ekitei shiko, 264-265. Shashi gives language from another official order for the same year strictly prohibiting the transport of commercial cargo under daimyo seal, 67.

${ }^{85}$ Hirooka Haruji gives a full account of the development of the Hachiman couriers, 37-38. The date of 1753 is given in Shashi, 67.
} 
the "Reizei freight" included not only the cargo of the court nobility, but also commercial goods handled by the Ōmi merchants.

The Edo merchant couriers naturally wanted to use symbols of their patrons' power to ship commercial and official items together, and they petitioned for the right to do so. ${ }^{86}$ The implications of the request are worth noting. Had the Edo carriers been allowed to ship cargo at fixed low rates with other protections guaranteed under the guild license, they would have priority only below that of bakufu officials at stations in freight transfer and acquisition of man and horse. The policy might have been disastrous for the stations. The bakufu denied the request and continued to issue warnings against the mixing of commercial and official cargo; the first such order in 1751 was followed by similar warnings in 1758 and $1776 .^{87}$

The abuse of shipping commercial goods under official seal came to a head in 1799 when the transport agents for five stations in the Kyoto region sent a petition to the Kyoto city magistrate complaining of the hardships the carriers' practices brought to their stations. Cargo traveling under the seals of Castle officials, court nobles, and the Houses of Mito, Kii, Owari, Hitotsubashi and others, they explained, had increased dramatically [through the Tenmei and Kansei years] while the amount of commercial cargo had fallen by half. ${ }^{88}$ It was in the transport of commercial goods that station agents hoped to make money-at least enough to help underwrite the duty of transporting official freight. The loss of horses and able-bodied porters in the stark Tenmei years was a critical issue: for the merchant carriers it made the use of official seals an imperative; for the stations any such abuse of the system exacerbated an already difficult situation. ${ }^{89}$ In this case it was not the Edo merchant houses, but rather their Kyoto counterparts who were the defendants in the suit. After a ten-month investigation fifty-nine persons attached to the Kyoto businesses were punished. Thirteen were banished from residence in Edo, Kyoto, Osaka, Sakai, Nara, Fushimi, Nagasaki, Nagoya, Wakayama, and Mito, banned from using the main highways, had their properties confiscated, and were fined. Thirty-four were sentenced to public display in handcuffs; the remainder received lesser punishments (a note at the end of the document explains that the verdicts were not sent down until the third year, 1802)..$^{90}$

Responding to the pressures for reform, the next year (1803) the Edo carriers' guild, under the direction of Osakaya Mohei, established new procedures and bylaws in two sets of documents, signaling a move toward greater internal cooperation. ${ }^{91}$ A document in fifty-three articles covered procedures for selecting officers, processes and schedules for the different kinds of mails (including a template for delivery certification), costs of mails based on weight and kind, and the like. They also delineated the carriers' duty to inform authorities in case of civil disturbance, natural disaster, impassable rivers, and the like. ${ }^{92}$ The thirty articles of the bylaws, recorded by the other leading house, Shimaya, were prescriptive in tone. They enjoined the guild members to uphold guild rules and to refrain from the kind of competitive practices that had undermined the guild in the past.

By 1793 merchant carriers in Osaka, Kyoto, Fushimi, as well as the 194 members of the Edo mukumi transporters, had received official recognition as guilds. In turn, each group issued templates of guild certification documents that were attached to cargo so that shipments could be verified, and also to curtail abusive practices by couriers (whose names would be on the certifications). ${ }^{93}$ In theory then, the guilds could expect that their cargo would be carried between stations in the order it was sent, and that they would not have to wait for days at certain

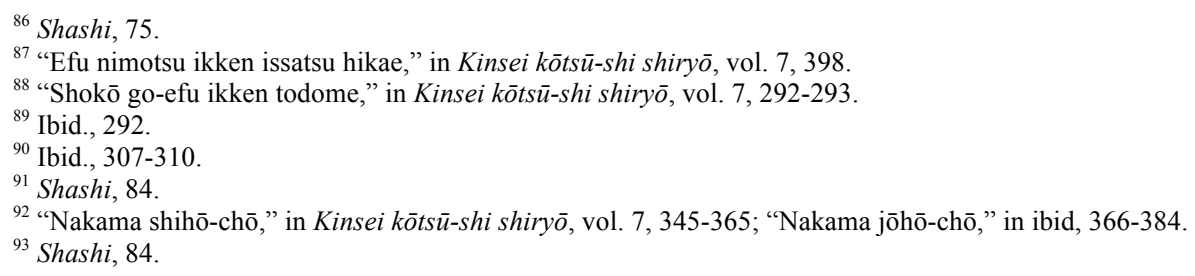


stations while other transporters received preferential treatment. The Edo mukumi hikyaku had, for the most part, defined themselves as cargo carriers for the daimyo, particularly on occasions of alternate attendance. In this way, they did not encroach on the business of the Edo merchant couriers. For a brief period at the beginning of the nineteenth century, the merchant couriers seemed to be prospering. ${ }^{94}$

The problems that guild organization was to have solved - delays at stations due to insufficient horses and men, and abuses by station transport agents - seem to have again worsened by the late 1820 s. In 1830 the guild petitioned the Commissioner of Highways complaining that stations had reverted to pre-Tenmei conditions: there were few horses and two to three-day delays at each station was once again the norm; transport agents and their subordinates were demanding gratuities to expedite transfers; and violent extortions by porters were on the rise. In short, the Edo merchant carriers asked that an order once again be sent to stations reminding them that because merchant cargo contained official goods and letters it was to be treated in the same manner as goods traveling under official seal. The bakufu sent the order, but apparently to little effect. ${ }^{95}$

\section{Dissolution and Reorganization of Transport Guilds: Toward Company Integration}

The Tenpo years (1830-1844) saw successive crop failures and famine that recalled for many the devastation of the Tenmei era. While the crop failures of the Tenmei era had been the worst in the northern regions of Honshū, those of the Tenpō era were extended into the southern regions of the main island. ${ }^{96}$ The effects on transporters were much the same as they had been fifty years before. Grain for horses was in short supply or nonexistent, and lawlessness on the roads increased with an influx of desperate people in search of sustenance. In 1838 the carriers and their managers took it upon themselves to work out compromises with each station and sent representatives along the Tōkaidō for that purpose. The next year they worked out a plan to set aside ten percent of fees (gojo moto dachinsen) to be paid out to the stations. In exchange, the stations would restore order to shipping and transfers and control unruly porters. ${ }^{97}$

It was in the context of the Tenpō calamities that the bakufu — as well as many individual domainsbegan to undertake a series of economic and social reforms (known collectively as the Tenpō Reforms). Some measures, such as prohibitions against luxurious clothing and extravagant behavior, were aimed at stopping wasteful practices among commoners. Others, such as attempts to stop migrants from entering Edo and to return those living in Edo to their native homes, were meant to relieve strains on the bakufu budget and to encourage commoners to increase the tax base through a return to farming. The bakufu also attempted to wrest control of commerce from the guilds, banning guilds in 1841.. The "six associations" (mukumi) transporters' guild was dissolved in Tenpō 12.12 (early 1842); the Edo private merchant couriers' guild was dissolved in Tenpō 13.6 (1842).

Recognizing that the dissolution of the guilds had not achieved their intended results, the bakufu lifted the bans in 1852, and courier guilds were quickly reorganized. Few records exist indicating what became of the couriers after the Tenpō reforms, but the decree recognizing the reorganization of the guild lists five members: Kyōya Yohei, Yamadaya Hachizaemon, Shimaya Sōemon, Izumiya Jinbei, and a new member, Edoya Jinzaburō. While the number of large transport companies in Edo, at least, dwindled, the need for communications did not flag.

\footnotetext{
${ }^{94}$ Ibid., 89 .

${ }^{95}$ Ibid., 91-92.

${ }^{96}$ Harold Bolitho, "The Tempō Crisis," in The Cambridge History of Japan, Vol. 5, ed. Marius B. Jansen (Cambridge: Cambridge University Press, 1988), 117-119.

${ }^{97}$ Shashi,92.
} 
If anything, the opening of Japan by Commodore Matthew Perry in 1853 and the subsequent opening of Yokohama and other ports to foreign trade after 1859 only spurred the need for greater integration of communications networks.

\section{Conclusion}

In 1871 the fledgling Meiji government announced plans to create a national postal system. Here is the announcement as it appeared in English-language newspapers of the day:

It is of greatest importance for public and private objects to facilitate as far as possible communication by post. Hitherto this service has been entirely left to private enterprise, so that great delay has frequently occurred in the transmission of letters. Sometimes it has required more than ten days for a letter to arrive at a distance of a hundred miles or so, while in other cases there was fear that letters never reached their destination at all. The charge for letters required to be forwarded with expedition has been very high, and the poorer classes in remote parts of the country have been entirely shut out from mutual intercourse. From the difficulty of learning the condition of affairs and the market prices of produce in different parts, it has often happened that groundless rumors have been spread abroad, and the public mind has been misled thereby. The knowledge of these facts has excited our profoundest commiseration.

It is therefore our intention gradually to inaugurate a general system of Posts on all the high-roads of the Empire, so that there may be inter-communication of thought between the remote points, and the state of affairs throughout the country be ascertained with ease and quickness, so that all classes may be able to have their letters forwarded with the greatest possible expedition. ${ }^{98}$

The Meiji government took pains to make a distinction between the purposes of the national postal system it proposed and the practices of the Tokugawa era, which were blamed for keeping Japanese in a state of mutual isolation. This study makes clear, however, that the complex and uneven state of communications in Tokugawa Japan had as much to do with the development of commercial relations, political organization, and infrastructure as it did with the practices of the private courier houses. The merchant couriers of the large cities, as we have seen, were operating over a dual-purpose transportation system that privileged the needs of the authorities over other users. By extension, then, official communications took priority over private and commercial letters and freight. Fast, efficient service is presumably the lifeblood of the communications trade, but under the conditions of the Tokugawa period it was difficult to provide efficient communications even under the best of circumstances. Laws commanded that freight be transferred from horse to horse at each station. The station agents, after handling the needs of official transporters, were to accommodate other travelers and transporters in the order they arrived. The stations were to offset financial strain placed on them through the fees paid by regular travelers; the couriers made their money by keeping transport expenses as low as possible. As a result, the couriers consistently abused the seals and emblems that allowed for low-rate or duty-free horse and manpower by intermingling commercial and official letters and items.

98 “A Japanese Post Office,” The Japan Weekly Mail, 29 April 1871. The Japanese version maybe found at Yūseishō, Yūsei hyakunenshi nenpyō (Tokyo: Yoshikawa Kōbunkan, 1972), 8. 
While there is as yet no conclusive evidence, it is possible that the abolition of guilds as part of the Tenpō reforms hurt some couriers and aided others as opportunities to expand clientele at the expense of other couriers presented themselves. In addition, as interregional commercial activities intensified, so too did the need for more extensive communications networks. Thus, in spite of the political upheavals of the 1850s and 1860s, and despite continuing problems at the post stations, the urban couriers that had survived had developed cooperative networks that connected castle towns and regional commercial centers.

Even as transport was fragmented and disrupted by the events of the Meiji Restoration, the merchant couriers continued to provide their services. Communications officials in the new Meiji government were aware of the need for reform, but even among those who knew of Western postal systems, none had the expertise or practical experience to implement such a system. At the same time, practices and relationships among those long involved in transport held fast. If merchants with interregional business could manage their communications with confidence through existing arrangements there was little incentive for them to use the new post unless it could improve on the service of the hikyakuya couriers. The hikyakuya, seeing their businesses threatened by the new post, responded to the threat by lowering prices. For a short time in the early Meiji period the survival of the new national post was in jeopardy. Finally, Maejima Hisoka was able to convince the couriers to reestablish themselves as specialists in parcel transport and as subsidized transport agents of the Japanese postal system.

Nittsū's company history provides an essential and compelling picture of overland communications in the Tokugawa, but the story is incomplete. There is still much work to be done to fully understand how the merchant couriers managed their businesses, how they coordinated with other regional companies, and whether and to what extent maritime and overland communications were integrated before the Meiji period. These questions and more remain, but like the fictional character Hanzō of Before the Dawn, we find that little-noticed shifts in communications brought dramatic changes to Japanese society as it became increasingly connected to the rest of the world.

\section{Glossary}

$\begin{array}{ll}\text { bashaku } & \text { 馬借 } \\ \text { chijimi hikyaku } & \text { 縮飛脚 } \\ \text { efu } & \text { 絵符-会符 } \\ \text { hikyakuya } & \text { 飛脚屋 } \\ \text { hyō } & \text { 俵 } \\ \text { Izumiya } & \text { 和泉屋 } \\ \text { jitte } & \text { 十手 } \\ \text { jō-bako } & \text { 状箱 } \\ \text { jō-bikyaku } & \text { 定飛脚 } \\ \text { junban-hikyaku } & \text { 順番飛脚 }\end{array}$




\begin{tabular}{|c|c|}
\hline Jūshichiya & 十七屋 \\
\hline kachi metsuke & 徒士目付 \\
\hline koku & 石 \\
\hline kome hikyaku & 米飛脚 \\
\hline kane-bikyaku (hikyaku) & 金飛脚 \\
\hline Kōshū & 甲州 \\
\hline machi bugyō & 町奉行 \\
\hline mukoku & 無刻 \\
\hline mukumi hikyaku & 六組飛脚 \\
\hline mura tsugi & 村継-村次 \\
\hline mura okuri & 村送 \\
\hline myōgakin & 冥加金 \\
\hline Naikoku Tsūun Kaisha & 内國通運会社 \\
\hline Nakasendō & 中山道-中仙道 \\
\hline Nikkō & 日光 \\
\hline nuki-jōo & 抜状一擢状 \\
\hline Ōshū & 奥州 \\
\hline Reizei Chūnagon & 冷泉中納言 \\
\hline ri & 里 \\
\hline Riku'un Moto Gaisha & 陸運元会社 \\
\hline rōjū & 老中 \\
\hline sadamegaki & 定書 \\
\hline sairyō & 宰領-才領 \\
\hline
\end{tabular}


sando-bikyaku

sankin kōtai

shichi-ri hikyaku

shōhō kaisho

shoshidai

te-ita

tenma yaku

Tōkaidō

tonya (toiya)

tsugi-bikyaku

Yoake mae
三度飛脚

参勤交代

七里飛脚

商法会所

所司代

手板

伝馬役

東海道

問屋

継飛脚一次飛脚

『夜明け前』 